Małgorzata Agnies zk a Sa m u jło
ORCID:0000-0003-1029-6020
Uniwersytet Marii Curie-Skłodowskiej w Lublinie

Teresa Sokołowska-Dzioba ORCID:0000 000304795237

Uniwersytet Marii Curie-Skłodowskiej w Lublinie

\title{
Zagospodarowanie czasu młodzieży w kontekście środowiska rodzinnego i szkolnego
}

\section{Time Management of Youth in the Context of Family and School Environment}

\begin{abstract}
ABSTRAKT
Rodzina i szkoła sq ważnymi przestrzeniami oddziaływającymi na nabywanie kompetencji w zakresie gospodarowania czasem przez uczniów. Każda z tych przestrzeni zajmuje określonq pozycję w procesie rozwoju młodzieży. Rodzina uczy planowania i gospodarowania czasem. Praca nauczycieli powinna kontynuować nabywanie przez uczniów umiejętności w sekundarnym kontekście rozwojowym. Kompatybilność tych środowisk jest warunkiem koniecznym do efektywnego planowania budżetu czasu przez młodzież.

Rozpatrując rolę czasu w życiu jednostki, celem badań było poznanie, jaki jest budżet czasu uczniów oraz jak przestrzeń środowiska rodzinnego i szkolnego sprzyja jego zagospodarowaniu.

W celu zgromadzenia danych empirycznych wykorzystano wykresy, na których 97 badanych uczniów szkół ponadpodstawowych miało
\end{abstract}

SPI Vol. 22, 2019/2

ISSN 2450-5358

e-ISSN 2450-5366

DOI: 10.12775/SPI.2019.2.007

Nadesłano: 07.10 .2018

Zaakceptowano: 31.05 .2019

Raporty z badań 
ukazać ilość czasu przeznaczonego w ciqgu doby i tygodnia na różne czynności. Inne aspekty zagospodarowania czasu przez młodzież, a także udział rodziny i szkoły jako znaczących miejsc, w których młodzież przebywa, określono na podstawie kwestionariusza ankiety.

Uzyskane wyniki skłaniaja do refleksji, że pobył w szkole i odrabianie lekcji dominuja, co można tłumaczyć tym, że edukacja jest podstawowq formq akływności młodzieży. Jednak czas poświęcony na niq znaczqco ogranicza czas wolny, co nie zawsze pozwala na dostateczny odpoczynek. Dostrzeżono, że sposób spędzania czasu z rodzicami ma charakter bierny, natomiast nauczyciele w małym zakresie kompensuja niekorzystne wzory gospodarowania czasem kształtowane w rodzinie.

\section{ABSTRACT}

Family and school are important spaces influencing the acquisition of competences in time management by students. Each of these spaces occupy a particular position in the process of youth development. The family teaches planning and time management. Teachers' work should continue to foster skills in a secondary development context. The compatibility of these environments is a prerequisite for effective time budget planning by the young people.

Considering the role of time in the life of an individual, the aim of the research was to know what is the time budget of students and how the space of the family and school environment is conducive to its development.

In order to collect the empirical data, charts were used in which 97 tested pupils from secondary schools were asked to show the amount of time devoted during the day and week to various activities. Other aspects of time management by the young people as well as the participation of family and school as significant places in which young people reside were determined based on a questionnaire survey.

The obtained results lead to the conclusion that staying at school and doing homework dominates, which can be explained by the fact that education is the basic form of youth activity. However, the time devoted to it significantly limits free time, which does not always allow for sufficient rest. It was noticed that the way of spending time with parents is passive, while teachers to a small extent compensate for unfavorable patterns of time management shaped in the family. 


\section{Wprowadzenie}

Wychowanie jednostek należy rozpatrywać w określonym miejscu i czasie. Miejsca znaczące dla dzieci to dom i szkoła. Funkcjonując i ucząc się w tych przestrzeniach, nie zdają sobie często sprawy, że kreują one ich aktywność i doświadczenia. Miejscem, w którym dzieci czują się naturalnie i swobodnie jest rodzina. Jest to „rodzaj mikroprzestrzeni, mogącej odgrywać rolę zarówno sfery prywatnej, jak i publicznej. Jest najbliższą człowiekowi, w jakiś sposób zamknię-

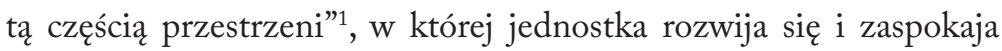
swoje potrzeby. W rodzinie jest otoczona zasadami, normami, zwyczajami, które symbolizują jej dom. Różne role w rodzinie determinują zachowania, oczekiwania, obowiązki i przywileje jej członków. Aby efektywnie pełnić rolę dziecka, ucznia, kolegi, jednostka musi sprostać kierowanym wobec niej wymaganiom. W procesie socjalizacji nabywa wzorce obowiązujących w społeczeństwie zachowań. Prawidłowe relacje $\mathrm{w}$ rodzinie powinny wiązać się ze świadomością potrzeb innych jej członków i reagowaniem na nie zgodnie z przyjętymi normami regulującymi wzajemne interakcje. Wskaźnikiem jakości funkcjonowania rodziny jest dopasowanie się do siebie i uzupełnianie w związku z pełnieniem ról i oscylowaniem między stałością a zmiennością zachowań ${ }^{2}$. Jeśli członkowie rodziny elastycznie traktują wypełnianie ról, łatwiej dostrzegają potrzeby psychiczne dziecka i właściwie ukierunkowują jego aktywność. Wychowanie wiąże się z okazywaniem wsparcia, troską o innych, tworzeniem dobrej atmosfery sprzyjającej poczuciu bezpieczeństwa w nawiązywanych relacjach. Rodzice stymulują rozwój fizyczny, poznawczy, społeczny, emocjonalny, zarządzają systemem rodzinnym, podejmują decyzje, przejmują odpowiedzialność za właściwe gospodarowanie czasem swoim i dzieci. Wypracowują schematy, które gwarantują właściwe postępowanie dzieci, zapobiegają problemom w zachowaniach oraz uczą ich odpowiedzialności i zdyscyplinowania.

Ważnym wyróżnikiem życia rodzinnego jest transmisja międzypokoleniowa, nadająca jej ponadczasowy charakter, warunkujący

1 M. Mendel, Kategoria miejsca w pedagogice, w: Pedagogika miejsca, red. M. Mendel, Wrocław 2006, s. 21-22.

2 W. Świętochowski, Rodzina w ujęciu systemowym, w: Psychologia rodziny, red.

I. Janicka, H. Liberska, Warszawa 2014, s. 34-38. 
adaptację wszystkich członków do kontekstu otaczającej rzeczywistości. Zabezpiecza to ciągłość zachowań przekazywanych przez rodzinę, ale też wyznacza kierunek i zakres zmian wynikających $\mathrm{z}$ dynamiki zmian społecznych. Transmisja wiąże się z przekazem ponadjednostkowym, specyficznym dla niej jako grupy społecznej (obrzędy, tradycje, procedury) i dotyczącym jednostki, a zwłaszcza jej cech i postaw. Może być ona rozpatrywana z uwagi na przekazywane między pokoleniami treści, sposoby ich podania, miejsca oraz skuteczność działań. Przekazowi rodzinnemu sprzyjają takie procesy, jak naśladowanie, modelowanie i identyfikacja poprzez obecność modeli, jakimi są rodzice ${ }^{3}$.

Kolejnym miejscem kształtującym osobowość jednostki jest przestrzeń szkoły. Zagospodarowanie przestrzeni szkolnej można traktować jako bazę dydaktyczno-wychowawczą i rozpatrywać zakres i możliwości właściwego wykorzystania oraz jej dostępności dla uczniów. Funkcjonalność przestrzeni w szkole może być źródłem informacji, jakie są oczekiwania na określonym poziomie edukacji. Systematycznie wzrasta liczba placówek, które dają uczniom poczucie bezpieczeństwa, inspirują do pracy i sprzyjają rozwojowi jednostek. Odpowiednie zorganizowanie przestrzeni stanowi niezbędne wzmocnienie dla przekazywanych przez nauczycieli komunikatów werbalnych i niewerbalnych. Wyposażenie szkoły jest informacją o tym, jak uczniowie mogą w niej funkcjonować. Daje możliwość podejmowania decyzji o sposobach wykorzystania czasu na lekcjach i na zajęciach pozalekcyjnych. Aranżacja przestrzeni szkolnej ułatwia uczniom adaptację do warunków szkolnych, a ponadto sygnalizuje zasady i reguły obowiązujące $\mathrm{w}$ danej przestrzeni.

Zagospodarowanie przestrzeni szkolnej warunkuje zachowania dzieci, które mogą też determinować działania nauczycieli i wpływać na decyzje o sposobie organizacji środowiska fizycznego i wykorzystania czasu. Usytuowanie dzieci w rzeczywistości szkolnej powinno być adekwatne do oferowanych im czynności, zadań. Poprzez odpowiednie zorganizowanie przestrzeni można uczniów zachęcać do przejawiania inicjatywy, pomysłowości, czy też szeroko rozumianej

3 M. Farnicka, H. Liberska, Transmisja międzypokoleniowa-procesy zachodzace na styku pokoleń, w: Psychologia rodziny, red. I. Janicka, H. Liberska, Warszawa 2014, s. 186-187. 
kreatywności albo skłaniać do bierności i wycofywania się z aktywności jednostkowej i grupowej. Środowisko fizyczne szkoły mówi o przyjętej koncepcji nauczania, o postawach nauczycieli wobec uczniów i preferowanych celach edukacyjnych ${ }^{4}$. Warto ponadto podkreślić, że przestrzeń szkoły powinna stanowić miejsce, w którym przebywające w nim osoby będą podejmowały działania w pełnym zaufaniu wobec siebie, będą uczyły się werbalizować swoje myśli i prezentować publicznie swoje pomysły i rozwiązania. Właściwie zorganizowane środowisko umożliwia dostosowanie działań do indywidualnego tempa pracy. Sprzyja też nabywaniu umiejętności w zakresie skutecznego realizowania podjętych celów, a ponadto pozwala odpowiednio wybierać i wykorzystać materiały ułatwiające rozwój osobisty 5 .

Istotne jest, by w szkole zmieniać zbyt ubogie środowisko fizyczne, by stało się ono stymulujące, a wręcz pobudzające entuzjazm do nauki. Partnerami w kreowaniu przestrzeni powinni być uczniowie, często pomijani, chociaż przede wszystkim to ich potrzeby należy zaspokajać podczas pobytu w klasach. Przyjazne miejsca w szkole powinny skłaniać uczniów do intensywnej i wytrwałej pracy własnej, dawać poczucie zadowolenia, co kształtuje u nich umiejętności społeczne, a ponadto daje możliwości rozwijania potencjału poszczególnych jednostek.

Ze względu na relatywnie długi czas przebywania uczniów w szkole wszystkie podmioty bliskie uczniowi powinny czuć się zobligowane do zapewnienia miejsc, które chroniłyby prywatność i intymność uczniów. Specyfiką szkoły jest to, że ,jako definiowana społecznie przestrzeń edukacji składa się z wielu warstw"6.

Pracujący w szkole nauczyciele ustanawiają procedury, motywują do nauki i samorozwoju oraz kontrolują i koordynują osiąganie celów uwzględniających potrzeby uczniów. Realizując cele dydaktyczno-wychowawcze w przestrzeni szkolnej w perspektywie czasowej nauczyciele wchodzą w kontakty, które powinny budować dobre relacje z różnymi wychowankami, realizując funkcje interakcyjne ${ }^{7}$. Szkoła

4 G. Dryden, J. Vos, Rewolucja w uczeniu, przeł. B. Jóźwiak, Wydawnictwo Moderski i S-ka, Poznań 2000.

5 R. Perry, Teoria i praktyka. Proces stawania się nauczycielem, przeł. B. Mazur, WSiP, Warszawa 2000, s. 103.

6 A. Nalaskowski, Przestrzenie i miejsca szkoty, Kraków 2002, s. 81.

7 K. Barnes, Wywieranie wplywu, przeł. Ł. Tuszyński, Gdańsk 2005, s. 26. 
wypełnia swoje zadania edukacyjne nie tylko poprzez przekazywanie treści ujętych $\mathrm{w}$ programach, ale także poprzez dialogi nauczycieli z uczniami w klasie i poza klasą szkolną, oparte na wzajemnym szacunku, modelowanym przede wszystkim przez nauczycieli, którzy aranżują sytuacje wyzwalające naturalne zachowania uczniów, wynikające $z$ ich świadomości. Tożsamość szkolną determinują interakcje szkolne wraz z otoczeniem wspierającym kształcenie uczniów i kreującym przestrzeń szkoły. Repertuar umiejętności podmiotów zaangażowanych w edukację przesądza o efektywnym współdziałaniu i wyznacza jakość pełnionych przez nauczycieli zadań organizacyjnych ${ }^{8}$.

Zapewnienie uczniom dobrych warunków do nauki będzie możliwe wtedy, gdy szkoła stanie się instytucją, ,która nieustannie się zmienia, wyprzedzając swoją ofertą oczekiwania potencjalnych klientów" Taką konieczność wymusza wizualizacja życia i recepcja dynamicznie docierających do uczniów bodźców w kontekście nieustannie zmieniającej się rzeczywistości.

W przestrzeni środowiska rodzinnego i szkolnego czas stanowi wartościowy element, którym uczą zarządzać osoby oddziaływające wychowawczo. „Czas jest najbardziej wartościowym z posiadanych przez nas dóbr, uderza spostrzeżenie, jak mało uwagi poświęcamy sposobom, w jaki go spędzamy"10. W procesie dydaktyczno-wychowawczym właściwe wykorzystanie czasu rozstrzyga o efektywnym funkcjonowaniu i prestiżu szkoły. Czas spędzany w szkole i wydajne jego wykorzystanie maksymalizuje osiągnięcia edukacyjne uczniów. Nauczyciele w podejmowanych działaniach stają przed problemem, jak zagospodarować czas realizując określone zadania. Trafne rozwiązania nauczycieli w tym obszarze warunkowane są możliwościami i zdolnościami uczniów. W rozporządzaniu czasem uczniów priorytetowo należy traktować wyodrębnienie czasu na naukę oraz czasu pozostającego do ich indywidualnego zagospodarowania, który może wzbogacić rozwój jednostki. Ważna jest umiejętność planowania i konkretyzowania celów, które w określonym czasie trzeba osiągnąć. Sprecyzowanie działań sprzyja efektywnemu wykorzystaniu czasu

8 M. Zielińska, Jak reagować na agresje uczniów?, Gdańsk 2012, s. 8-9, 50-51.

9 Uczenie się metoda projektów, red. B.D. Gołębniak, Warszawa 2002, s. 5.

10 P. Zimbardo, J. Boyd, Paradoks czasu, przeł. A. Cybulko, M. Zieliński, Warszawa 2009, s. 17. 
i daje uczniom poczucie sukcesu i zadowolenia ze sprawności własnego działania. Natomiast nieuzasadnione wydłużanie czasu działania zniechęca i obniża percepcję sprawności w zakresie skuteczności działania.

Wychowawcy w znacznym stopniu kształtują osobiste postrzeganie wykorzystania czasu, czyli możemy stwierdzić, że jest to umiejętność wyuczona. Istotne zatem staje się rozwijanie u uczniów własnej perspektywy postrzegania czasu, budowanie świadomości upływającego czasu i konieczności maksymalnego wykorzystania go w różnych sytuacjach życiowych i w przestrzeni. Doświadczenia kształtują wzorce postępowania, które mogą być powtarzalne, a zatem sprzyjające harmonogramowi działania i przewidywaniu jego skuteczności, czyli realnemu planowaniu i efektywnemu osiąganiu celów. Realna „perspektywa czasu jest fundamentem sposobu, w jaki ludzie żyją (...). Ludzie zorientowani na przyszłość odnoszą na ogół większe sukcesy zawodowe i akademickie, lepiej się odżywiają, regularniej ćwiczą swoje ciało", troszcząc się o swoje zdrowie, a także pomagają innym osobom w trudnych sytuacjach ${ }^{11}$.

Rozpatrując działania uczniów, należy brać pod uwagę różnice międzypłciowe w obszarach funkcjonowania społecznego. Rodzice są pierwszymi nadawcami przekazów na temat płci, tworząc często odmienne środowiska córkom i synom. Wzmacniają tradycyjne role płciowe poprzez zadania związane $\mathrm{z}$ wypełnianiem codziennych obowiązków domowych oraz przejawiane oczekiwania wobec dzieci zależnie od płci. Socjalizacja rodzinna na ogół kontynuowana jest w przestrzeni szkolnej. Stereotypowość płci determinuje też określone zachowania dziewcząt i chłopców, związane z gospodarowaniem czasem $^{12}$. Wsparcie ze strony rodziców, odpowiednie relacje $z$ rówieśnikami w sytuacjach edukacyjnych, których podstawą jest często aktywność fizyczna sprzyja kształtowaniu adekwatnej samooceny

1 Tamże, s. 24.

12 Psychologia spoteczna, red. A.S.R. Manstead, M. Hewstone, S.T. Fiske, M.A. Hogg, H.T. Reis, G.R. Semin, przeł. J. Gilewicz, Warszawa 1996, s. 351-356. 
w przeciwieństwie do stereotypowego spędzania czasu, gdy młodzież korzysta $z$ Internetu, czy sięgania po środki farmakologiczne ${ }^{13}$.

\section{Badania własne}

Zarządzanie czasem stanowi ważną umiejętność, zwłaszcza w dobie intensywnego tempa życia, dotykającego nie tylko osób pracujących zawodowo, ale także uczniów. Właściwe wykorzystanie czasu ma ogromne znaczenie dla jakości życia jednostki i jest jednym $z$ najistotniejszych wymiarów decydujących o efektywnym realizowaniu celów i odnoszeniu sukcesów. Dzieci i młodzież nie mają dostatecznie rozwiniętej świadomości jego roli w sprawności działań i poczuciu zadowolenia. Dorastający młody człowiek może dystansować się od przekazywanych przez rodziców, nauczycieli oraz rówieśników modeli zagospodarowania czasu bądź przyjmować je, kreując w biegu swojego życia indywidualny sposób postępowania i kształtując swoją tożsamość ${ }^{14}$. Wychowawcy powinni kształtować umiejętność gospodarowania czasem i podkreślać jej przydatność w codziennych sytuacjach i doznawaniu osobistej satysfakcji. Rozpatrując rolę czasu w życiu jednostki, przedmiotem badań uczyniono budżet czasu i gospodarowanie nim przez młodzież w kontekście środowiska rodzinnego i szkolnego. Mając na uwadze społeczny sposób funkcjonowania jednostek związany z rolami płciowymi, zagospodarowanie czasu przeanalizowano wśród dziewcząt i chłopców.

Problematyka badawcza została odniesiona do sposobu wykorzystania czasu w codziennych sytuacjach, z którymi młodzież spotyka się w rodzinie i szkole. Dostrzegając synergię tych środowisk, celem badań było poznanie, jaki jest budżet czasu uczniów oraz jak przestrzeń środowiska rodzinnego i szkolnego sprzyja jego zagospodarowaniu. Należy podkreślić, że są to środowiska szczególnie znaczące w rozwoju jednostek i w funkcjonowaniu społecznym.

W celu zgromadzenia danych empirycznych wykorzystano wykresy dobowego i tygodniowego „tortu życia”, w których badani mieli

13 A. Pisarska, K. Ostaszewski, K. Bobrowski, Czynniki ryzyka i czynniki chroniqce zwiqzane z problemami internalizacyjnymi młodzieży w okresie późnego dorastania, „Postępy Psychiatrii i Neurologii” 2018, t. 27, nr 4, s. 261-280.

14 M. Bardziejewska, Okres dorastania. Jak rozpoznać potencjat nastolatków?, Gdańsk 2005, s. 363-365. 
ukazać ilość czasu przeznaczonego w ciągu doby i tygodnia na różne czynności poprzez promieniste podzielenie na części czas doby i tygodnia. Narzędzie przygotowano na podstawie opisów ćwiczeń: „Tygodniowy tort życia” w Programie profilaktycznym dla młodzieży "Jak żyć z ludźmi”"15 oraz „Zegary”" Drugim narzędziem był kwestionariusz ankiety, dotyczący innych aspektów zagospodarowania czasu przez młodzież, a także udziału rodziny i szkoły jako znaczących miejsc, w których młodzież przebywa.

Badania przeprowadzono wśród 97 uczniów szkół ponadpodstawowych na terenie województwa lubelskiego w 2017 roku. Badani uczniowie to 48 dziewcząt i 49 chłopców w wieku od 15 do 16 lat.

Sztuka zarządzania czasem przez młodzież pozwala na adekwatne jego wykorzystanie i realizowanie celów. Świadomość budżetu czasu, którym się dysponuje, daje szansę na właściwe jego zaplanowanie i zorganizowanie codziennych czynności, co zwiększa skuteczność działań. W tabeli 1 ukazano, jak młodzież dzieli czas w ciągu doby na poszczególne czynności.

Tabela 1. Dobowy budżet czasu dziewcząt i chłopców

\begin{tabular}{|l|c|c|c|c|}
\hline \multirow{2}{*}{ Czynności } & \multicolumn{2}{|c|}{ Dziewczęta } & \multicolumn{2}{c|}{ Chłopcy } \\
\cline { 2 - 5 } & Liczba godzin & $\%$ & Liczba godzin & $\%$ \\
\hline Sen & 7,73 & 32,2 & 7,20 & 30 \\
\hline Posiłki i higiena & 2,23 & 9,3 & 2,10 & 8,75 \\
\hline Pobyt w szkole & 7,30 & 30,4 & 6,90 & 29 \\
\hline Odrabianie lekcii & 2,40 & 10 & 1,56 & 6,5 \\
\hline Pozostałe obowiq̨zki & 1,76 & 7,3 & 2,58 & 10,75 \\
\hline Czas wolny & 2,60 & 10,8 & 3,58 & 15 \\
\hline
\end{tabular}

Źródło: badania własne.

Charakteryzując dobowy budżet czasu w percepcji młodzieży można dostrzec, że dziewczęta najwięcej czasu przeznaczają na sen i niewiele mniej na pobyt w szkole. Niemal dwie i pół godziny

15 Jak ̇̇yć z ludźmi. Program profilaktyczny dla mtodziė̇y, MEN, Warszawa 1989 , s. 2-7.

16 M. Chomczyńska-Miliszkiewicz, D. Pankowska, Polubić szkołe, Warszawa1995, s. 157. 
zajmuje im odrabianie lekcji na następny dzień. W podobnym wymiarze uplasował się czas wolny i kolejno czas poświęcony na posiłki i higienę. W przypadku chłopców możemy stwierdzić, że nieco mniej czasu poświęcają na sen i pobyt w szkole, na odrabianie lekcji, co pozwala im dysponować większą ilością czasu wolnego w wymiarze blisko czterech godzin.

Analiza tygodniowego budżetu czasu ukazała, że weekendy pozwalają na wydłużenie czasu przeznaczonego na sen, który waha się od 7,5 godziny na dobę u dziewcząt do 8 godzin na dobę u chłopców. Ponadto w ciągu tygodnia chłopcy mają o około dwie godziny dłuższy czas wolny niż dziewczęta.

Badana młodzież jako priorytetowe czynności w czasie wolnym wskazuje korzystanie z komputera i Internetu, koncentrując swą aktywność na grach, nieznacznie mniej ogląda telewizję, słucha muzyki, spotyka się z przyjaciólmi. Trzeba podkreślić, iż dziewczęta częściej niż ich koledzy słuchają muzyki i podtrzymują relacje towarzyskie. Uprawianie sportu jako zajęcie w czasie wolnym jest wskazywane przez ponad jedną trzecią badanych chłopców i nieco mniej dziewcząt. Jeszcze mniejszym zainteresowaniem cieszy się czytanie książek, które częściej jest wskazywane przez dziewczęta niż chłopców. Sporadycznie jest deklarowane przez badanych wyjście do kina czy teatru. Około połowę grupy badanej stanowią uczniowie rozwijający w tym czasie swoje zainteresowania poprzez udział w zajęciach zorganizowanych. Jedna piąta deklaruje, że czyni to samodzielnie, zaś pozostali nie poświęcają czasu na rozwijanie swoich pasji.

Zdaniem M. Czerepaniak-Walczak ${ }^{17}$ „czas wolny jest interwałem podmiotowego życia, w którym osoba doświadcza dobrostanu intelektualnego, emocjonalnego i fizycznego, w rezultacie możliwości samodzielnego, suwerennego przejawiania czynności posiadających znamiona dobrowolności i niekomercyjności oraz będących źródłem satysfakcji”. Specyficzne dla młodzieży jest wykonywanie wielu czynności jednocześnie, co powoduje trudności w jednoznacznym określeniu długości czasu wolnego. Warto też zauważyć, że czas wolny jest cechą jednostkową, zależną od osobowości, systemu wartości i doświadczeń nabywanych w rodzinie i szkole.

17 M. Czerepaniak-Walczak, Od próżniaczenia do zniewolenia - w poszukiwaniu dyskursów czasu wolnego, w: Pedagogika spoteczna, red. E. Marynowicz-Hetka, Warszawa 2007, s. 236. 
W okresie adolescencji specyficzne jest to, że kryterium wyboru przyjaciół stają się zainteresowania, np. sportem lub muzyką. Często występuje zbieżność rozwijania własnych pasji z podtrzymywaniem, a wręcz wzmacnianiem przyjaźni. W grupie bliskie związki rówieśnicze zacieśniają się poprzez wspólne działania, wynikające z uprawianego hobby i przeznaczanego na to czasu ${ }^{18}$. Postrzegając przestrzeń środowiska rodzinnego jako znaczącą w rozwoju jednostki, rozpatrzono udział rodziców w organizowaniu czasu dzieci. Badani mogli wskazać więcej niż jeden rodzaj aktywności rodziców. Wyniki przedstawiono w tabeli 2.

Tabela 2. Udział rodziców w organizacii czasu dziewcząt i chłopców

\begin{tabular}{|l|c|c|c|c|}
\hline \multirow{2}{*}{ Kategorie czynności } & \multicolumn{2}{|c|}{ Dziewczęta } & \multicolumn{2}{c|}{ Chłopcy } \\
\cline { 2 - 5 } & $\mathbf{N}$ & $\%$ & $\mathbf{N}$ & $\%$ \\
\hline $\begin{array}{l}\text { Wspólne wyjazdy, spacery, wycieczki } \\
\text { rowerowe }\end{array}$ & 14 & 29 & 11 & 22 \\
\hline Oglaqdanie TV & 30 & 62 & 25 & 51 \\
\hline Wyjścia do kina, teatru & 3 & 0,6 & 1 & 0,2 \\
\hline Robienie zakupów & 25 & 52 & 18 & 37 \\
\hline Inne & 11 & 23 & 12 & 24 \\
\hline
\end{tabular}

Źródło: badania własne.

Środowisko rodzinne jest miejscem, które zapewnia najkorzystniejsze warunki bytowe dla rozwoju dziecka oraz dostęp do różnych źródeł poznawania ludzi, świata przede wszystkim poprzez media. Zarówno dziewczęta, jak i chłopcy najczęściej razem $\mathrm{z}$ rodzicami oglądają telewizję. Taką opinię przedstawiła ponad połowa badanych. Jako kolejną formę aktywności można wskazać wspólne wyjazdy, spacery. Należy przypuszczać, że jest to związane ze sportem i rekreacją. Być może z uwagi na tematykę repertuaru kinowego i teatralnego oraz łatwość dostępu do mediów elektronicznych dziewczęta i chłopcy w okresie adolescencji nie postrzegają rodziców jako partnerów w odniesieniu do tej formy rozrywki. Badani w innych czynnościach lokowali rozmowy z matkami, ojcami na różne tematy.

18 D. Boyd, H. Bee, Psychologia rozwoju cztowieka, przeł. A. Wojciechowski, Poznań 2008, s. 383. 
Część podkreślała, że miały one charakter bardzo osobisty. Niektórzy uczniowie wskazali możliwość towarzyszenia przy realizacji pasji rodziców, np. podczas „wędkowania”, „majsterkowania” czy „robienia zakupów”.

Ze względu na obecność rodziców w zagospodarowaniu czasu dzieci ponad połowa $\mathrm{z}$ nich podkreślała, że $\mathrm{w}$ czasie pozostającym do własnej dyspozycji towarzyszą im matki, ojcowie. Są oni także zainteresowani sposobem spędzania przez dzieci czasu wolnego. Nieco mniej niż połowa badanych uważa, że rodzice kontrolują ich w tym czasie. Jednak przy wskazaniu osoby, która decyduje o sposobie spędzania czasu wolnego ponad $80 \%$ stwierdza, że od nich samych zależy rodzaj jego zagospodarowania, który często jest inspirowany propozycjami rówieśników. Pomimo tego jedna piąta badanych nie jest zadowolona ze sposobu organizowania czasu, którym dysponują.

Przemiany dokonujące się we wszystkich dziedzinach życia wnoszą różne jakościowo nowe sposoby zagospodarowania czasu. Równolegle $\mathrm{z}$ tradycyjnymi zajęciami w czasie wolnym rozwija się kultura wirtualna i jednostki stają przed koniecznością wybierania nowych sposobów zachowania, metod uczenia się, wartościowania, porozumiewania z innymi ludźmi. Można oczekiwać, że przygotowanie do uczestnictwa w obecnej rzeczywistości, w której dostępne są nowoczesne technologie, przejmie w dużym stopniu edukacja szkolna, wzbogacająca przestrzeń środowiska rodzinnego dziecka.

Tabela 3. Zajęcia dodatkowe oferowane uczniom przez szkołę

\begin{tabular}{|l|c|c|c|c|}
\hline \multirow{2}{*}{ Rodzaje zajęć } & \multicolumn{2}{|c|}{ Dziewczęta } & \multicolumn{2}{c|}{ Chłopcy } \\
\cline { 2 - 5 } & N & $\%$ & N & $\%$ \\
\hline Matematyczne & 12 & 25 & 11 & 22 \\
\hline Informatyczne & 6 & 12 & 14 & 28 \\
\hline Polonistyczne/teatralne & 5 & 10 & 4 & 8 \\
\hline Taneczne & 9 & 18 & 6 & 12 \\
\hline Muzyczne & 10 & 20 & 5 & 10 \\
\hline Sportowe & 18 & 37 & 23 & 46 \\
\hline Inne & 15 & 31 & 16 & 32 \\
\hline
\end{tabular}

Źródło: badania własne. 
W szkole młodzież spędza wiele godzin dziennie, ujawniając często różne talenty i zainteresowania, dla rozwoju których trzeba stworzyć odpowiednią przestrzeń i zapewnić profesjonalne działania nauczycieli. W szkołach, w których przeprowadzono badania, największą popularnością cieszyły się różne zajęcia sportowe, preferowane przez prawie połowę chłopców i nieco mniej dziewcząt. Może to być warunkowane tym, że zazwyczaj chłopcy przejawiają większą aktywność ruchową niż dziewczynki i potrzebują więcej przestrzeni ${ }^{19}$, bądź też specyfiką zajęć sportowych oferowanych w danej szkole. Rozpatrując łącznie zajęcia matematyczne i informatyczne można stwierdzić, że są wybierane przez połowę chłopców, lecz dziewczęta też ich nie pomijają. Zajęcia polonistyczne, teatralne nie są zróżnicowane ze względu na płeć uczniów i uczestniczy w nich około jedna dziesiąta badanych. Dziewczęta preferują zajęcia taneczne i muzyczne, które wśród chłopców cieszą się mniejszym zainteresowaniem. Prawie jedna trzecia badanych, niezależnie od płci, ujawniła, że korzysta $z$ innych dodatkowych zajęć, wymieniając na przykład zajęcia językowe, fotograficzne, historyczne, geograficzne. Udział uczniów w zajęciach organizowanych przez szkołę może być przez nich postrzegany jako uzupełniający wiedzę szkolną, np. zajęcia matematyczne, polonistyczne, bądź też budujący dodatkowe kompetencje, niezależne od celów dydaktycznych, co prawdopodobnie związane jest $\mathrm{z}$ wyborami uczniów w zakresie zajęć teatralnych czy fotograficznych.

Badani uczniowie uczestniczą także $\mathrm{w}$ zajęciach pozaszkolnych, które postrzegają jako możliwość dopełniania wiedzy szkolnej, ale też wysoko cenią sobie dodatkowe kontakty z kolegami i koleżankami, odbywające się w innej przestrzeni niż środowisko rodzinne i szkolne.

\section{Podsumowanie}

Bardzo ważną kwestią jest sposób wykorzystania czasu w okresie adolescencji. Młodzież kształtuje wówczas pewne nawyki, które przeniesie w życie dorosłe. Umiejętność zagospodarowania czasu będzie miała znaczenie w przyszłości, gdyż będzie sprzyjała bądź nie konstruktywnym formom aktywności.

19 R. Vasta, M.M. Haith, S.A. Miller, Psychologia dziecka, przeł. M. Babiuch, Warszawa 1995, s. 575. 
Analiza budżetu czasu uczniów zmusza do refleksji, że pobyt w szkole i odrabianie lekcji dominuje, co można tłumaczyć tym, że edukacja jest podstawową formą aktywności młodzieży. Jednak czas poświęcony na nią znacząco ogranicza czas wolny, którego odpowiednie zagospodarowanie stymuluje rozwój, uczy odpowiedzialności, samodzielności, pozwala na kreatywność. W budżecie uczniów czas wolny nie zawsze pozwala na dostateczny odpoczynek i regenerację oraz rekreację.

Rozpatrując czas badanej młodzieży w kontekście środowiskowym można dostrzec, że przebywanie $\mathrm{z}$ rodzicami ma najczęściej charakter bierny, np. oglądanie telewizji, lecz prawie o połowę mniej uczniów aktywnie spędza czas z matkami i ojcami. Specyficzną formą udziału rodziców w organizacji czasu jest wspólne robienie zakupów, które w większym stopniu dotyczy córek. Mając na uwadze, że na zagospodarowanie czasu istotny wpływ ma szkoła, w której pracują profesjonaliści, można stwierdzić, że spośród oferowanych zajęć pozalekcyjnych najbardziej atrakcyjne były zajęcia sportowe, ale zainteresowaniem cieszyły się też zajęcia muzyczne i taneczne. Inaczej należy spojrzeć na zajęcia $z$ obszaru matematyki, które były wybierane, ale być może głównie z powodu konieczności zrozumienia czy uzupełnienia wiedzy przedmiotowej. Trzeba podkreślić, że szkoła stwarza większą przestrzeń i inne warunki do rozwoju indywidualnego uczniów niż rodzina, ponieważ oddziaływanie jej wiąże się z przygotowaniem zawodowym wychowawców i umiejętnością konkretyzowania i realizowania celów. Ponadto kontekst społeczny stwarza możliwości nawiązywania wielu kontaktów rówieśniczych, które często są bardzo inspirujące i motywujące do działania.

Młodzież sporadycznie korzysta ze specjalistycznych dodatkowych zajęć w szkole, ale uczestniczy również w zajęciach pozaszkolnych, podkreślając, że nie są one tylko możliwością realizacji pasji, ale pozwalają budować znaczące relacje społeczne.

Zarówno w przestrzeni rodzinnej,jak i szkolnej dzieciom codziennie towarzyszą multimedia jako dominujący sposób rekreacji „wypełniając im czas wolny i niejednokrotnie czas zajęć obowiązkowych”20. gogiki spotecznej, w: Pedagogika spoteczna, red. E. Marynowicz-Hetka, Warszawa 2007, s. 519. 
Wykorzystując media elektroniczne, młodzi ludzie utrzymują określone relacje $\mathrm{z}$ różnymi podmiotami w sposób pośredni. Wchodzą w wirtualną rzeczywistość, stykając się z eksplozją informacji, które percypują w samotności i wobec których czują się bezradni. Ważne w tym kontekście jest wsparcie wychowawców i zarówno rodzice jak i nauczyciele muszą mieć pełną świadomość, że nastolatki chcą się od nich uniezależnić, a jednocześnie mieć poczucie wspólnoty z nimi ${ }^{21}$.

Udział rodziców w nauce i zajęciach pozalekcyjnych dzieci, a ogólnie rzecz biorąc $\mathrm{w}$ organizowaniu czasu, jest bardzo ważny w okresie dojrzewania. Zaangażowanie rodziców chroni młodzież przed problemami wychowawczymi, nieodpowiednimi zachowania$\mathrm{mi}^{22}$. Podkreślić należy rolę współpracy rodziców z nauczycielami, by dwie najważniejsze przestrzenie w rozwoju dziecka uzupełniały swoje oddziaływania i przekazywały uczniom umiejętność odpowiedniego planowania indywidualnego czasu. W triadzie uczniowie-rodzice-nauczyciele w kwestii edukacji związanej z zarządzaniem czasem konieczny jest rzeczywisty dialog między tymi podmiotami.

\section{Bibliografia}

Bardziejewska M., Okres dorastania. Jak rozpoznać potencjat nastolatków?, w: Psychologiczne portrety cztowieka, red. A.I. Brzezińska, GWP, Gdańsk 2005, s. 345-377.

Barnes K., Wywieranie wplywu, przeł. Ł. Tuszyński, GWP, Gdańsk 2005.

Boyd D., Bee H., Psychologia rozwoju cztowieka, przeł. A. Wojciechowski, Zysk i S-ka Wydawnictwo, Poznań 2008.

Chomczyńska-Miliszkiewicz M., Pankowska D., Polubić szkote, WSiP, Warszawa 1995.

Czerepaniak-Walczak M., Od próżniaczenia do zniewolenia - w poszukiwaniu dyskursów czasu wolnego, w: Pedagogika spoteczna, red. E. Marynowicz-Hetka, Wydawnictwo Naukowe PWN, Warszawa 2007, s. 219-236.

Dryden G., Vos J., Rewolucja w uczeniu, przeł. B. Jóźwiak, Wydawnictwo Moderski i S-ka, Poznań 2000.

Farnicka M., Liberska H., Transmisja międzypokoleniowa - procesy zachodzace na styku pokoleń, w: Psychologia rodziny, red. I. Janicka, H. Liberska, Wydawnictwo Naukowe PWN, Warszawa 2014, s. 185-201.

21 D. Boyd, H. Bee, Psychologia rozwoju cztowieka, dz. cyt., s. 379.

22 Tamże, s. 282. 
Izdebska J., Media elektroniczne jako obszar zainteresowañ wspótczesnej pedagogiki spotecznej, w: Pedagogika spoteczna, red. E. Marynowicz-Hetka, Wydawnictwo Naukowe PWN, Warszawa 2007, s. 518-533.

Jak żyć z ludżmi. Program profilaktyczny dla mtodzieży, MEN, Agencja Informacji Użytkowej, Warszawa 1989.

Mendel M., Kategoria miejsca w pedagogice, w: Pedagogika miejsca, red. M. Mendel, Wydawnictwo Naukowe Dolnośląskiej Szkoły Wyższej Edukacji TWP, Wrocław 2006, s. 21-37.

Nalaskowski A., Przestrzenie i miejsca szkoty, Oficyna Wydawnicza „Impuls”, Kraków 2002.

Perry R., Teoria i praktyka. Proces stawania się nauczycielem, WSiP, Warszawa 2000.

Pisarska A., Ostaszewski K., Bobrowski K., Czynniki ryzyka i czynniki chroniace zwiqzane z problemami internalizacyjnymi młodzieży w okresie późnego dorastania, „Postępy Psychiatrii i Neurologii” 2018, t. 27, nr 4, s. 261-280.

Psychologia spoteczna, red. A.S.R. Manstead, M. Hewstone, S.T. Fiske, M.A. Hogg, H.T. Reis, G.R. Semin, przeł. J. Gilewicz, Jacek Santorski \& Co Wydawnictwo, Warszawa 1996.

Świętochowski W., Rodzina w ujeciu systemowym, w: Psychologia rodziny, red. I. Janicka, H. Liberska, Wydawnictwo Naukowe PWN, Warszawa 2014, s. $21-45$.

Uczenie się metoda projektóww, red. B.D. Gołębniak, WSiP, Warszawa 2002.

Vasta R., Haith M.M., Miller S.A., Psychologia dziecka, przeł. M. Babiuch, WSiP, Warszawa 1995.

Zielińska M., Jak reagować na agresje ucznióww?, Harmonia Universalis, Gdańsk 2012.

Zimbardo P., Boyd J., Paradoks czasu, przeł. A. Cybulko, M. Zieliński, Wydawnictwo Naukowe PWN, Warszawa 2009.

\section{ADRES DO KORESPONDENCJI}

\section{Dr Małgorzata Agnieszka Samujło}

Uniwersytet Marii Curie-Skłodowskiej

Wydział Pedagogiki i Psychologii

Instytut Pedagogiki

e-mail: msamujlo@wp.pl

Dr Teresa Sokołowska-Dzioba

Uniwersytet Marii Curie-Skłodowskiej

Wydział Pedagogiki i Psychologii

Instytut Pedagogiki

e-mail: edzioba@op.pl 